\title{
Interfacial and emulsifying properties of amaranth (Amaranthus hypochondriacus) protein isolates under different conditions of $\mathrm{pH}$
}

\author{
Jorge L. Ventureira ${ }^{\mathrm{a}}$, Agustín J. Bolontrade ${ }^{\mathrm{a}}$, Francisco Speroni ${ }^{\mathrm{a}}$, Elisabeth David-Briand ${ }^{\mathrm{b}}$, \\ Adriana A. Scilingo ${ }^{a}$, Marie-Hélène Ropers ${ }^{b}$, Frank Boury ${ }^{c}$, María C. Añón ${ }^{a}$, Marc Anton ${ }^{b}, *$ \\ ${ }^{a}$ Centro de Investigación y Desarrollo en Criotecnología de Alimentos (CIDCA) (CONICET-CCT-La Plata - Facultad de Ciencias Exactas, UNLP), 47 y 116, La Plata (1900), \\ Buenos Aires, Argentina \\ ${ }^{\mathrm{b}}$ Institut National de la Recherche Agronomique, UR 1268 Biopolymères Interactions Assemblages, Equipe Interfaces et Systèmes Dispersés, INRA, BP 71627, \\ F-44316 Nantes Cedex 3, France

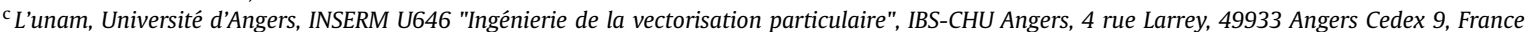

\section{A R T I C L E I N F O}

\section{Article history:}

Received 31 March 2011

Received in revised form

11 July 2011

Accepted 15 July 2011

\section{Keywords:}

Amaranth

Interfacial properties

Dilatational interfacial rheology

Langmuir isotherm

Emulsifying properties

\begin{abstract}
A B S T R A C T
Amaranth proteins have adequate amino acid balance for substituting either partly or completely animal proteins in human nutrition. However, they present poor emulsifying properties in basic conditions corresponding to their extraction medium. Consequently their use in acidic conditions could be envisaged to better exploit their potentialities. To better understand their emulsifying properties we have studied their interfacial activities at pHs 2.0 and 8.0 and tried to make the link between 2D and 3D properties.

Our results clearly demonstrate the better properties of $\mathrm{AI}$ at $\mathrm{pH} 2.0$ than at $\mathrm{pH} 8$ in terms of protein solubility, spreading, adsorption, viscoelastic properties of interfaces and emulsion stability. These results are in relation with the denaturated state of proteins at $\mathrm{pH} 2.0$ where proteins form a harder interfacial film, as compared to $\mathrm{pH}$ 8.0. Thus the potential use of amaranth proteins in emulsifying applications should be oriented towards acidic applications.
\end{abstract}

(C) 2011 Published by Elsevier Ltd.

\section{Introduction}

All the prospective studies announce at the horizon 2050 a shortage of animal proteins that could induce difficulties to ensure sustenance of the entire earth population. Therefore it is necessary to target new sources of proteins with good nutrition quality. The most promising source is plant proteins that could substitute either partly or completely animal proteins in human nutrition (Rodríguez Patino et al., 2007; Tavano, Da Silva Jr., Demonte \& Neves, 2008). Among the nonconventional seeds as sources of proteins, amaranth is one of the main capable, with a high protein content (14-19\%) (Salcedo-Chávez, Osuna-Castro, Guevara-Lara, Domínguez-Domínguez, \& Paredes-López, 2002) and an amino acid composition high in lysine and sulphur amino acids, better than those of cereals and legumes (Guzmán-Maldonado \& Paredes-López, 1998; Thanapornpoonpong, Vearasilp, Pawelzik, \& Gorinstein, 2008). The main fractions in amaranth isolates are albumins (10-40 kDa) and multimeric globulins with molecular weights of more than

\footnotetext{
* Corresponding author.

E-mail address: marc.anton@nantes.inra.fr (M. Anton).
}

180 kDa (Barba de la Rosa, Paredes-López, \& Gueguen, 1992; Bressani \& García-Vela, 1990; Martínez \& Añón, 1996).

Besides their good amino acid balance, the functional properties of amaranth proteins is important for food processing, and can be modified by extraction processes (Fidantsi \& Doxastakis, 2001; Tömösközi et al., 2008). The whole isolate does not exhibit good emulsifying and foaming properties at pH 8.0 (Tömösközi et al., 2008). Amaranth albumins (main fraction) have a higher emulsifying activity at $\mathrm{pH} 5.0$ while amaranth globulins exhibit their higher emulsifying properties at pH 7.0 (Silva-Sanchez, GonzalesCastenada, de Leon-Rodriguez \& Barba de la Rosa, 2004). The use of the amaranth protein isolates in food is thus conditioned by $\mathrm{pH}$. In order to improve the interfacial activity of amaranth protein isolates, their hydrolysates were produced (Ventureira, Martínez, \& Añón, 2010). Whatever the degree of hydrolysis and the action of enzyme (alcalase or trypsin) the increase in emulsifying activity is not strong enough to retain this pathway.

Consequently, acidification seems to be a good track as the emulsifying properties of the isolates are higher at $\mathrm{pH} 2.0$ than at pH 8.0 (Ventureira et al., 2010) and this was attributed to the lower size of polypeptides and a better solubility of proteins at $\mathrm{pH}$ 2.0. 
However, this latter paper did not advance any explanation on the behavior of amaranth proteins at the interfaces in relation with the understanding of their emulsifying properties at $\mathrm{pH} 2.0$ and 8.0.

Consequently, to better understand the potential of amaranth proteins as food emulsifiers, we have investigated their structure by circular dichroism and differential scanning calorimetry, and their interfacial activity at both air-water and oil-water interfaces at $\mathrm{pH}$

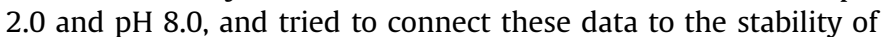
emulsions. Additionally we have compared the emulsifying properties of total protein fraction and only soluble fraction in view to assess the impact of aggregates.

\section{Materials and methods}

\subsection{Amaranth seeds and flour}

The seeds of amaranth were obtained from the Universidad Nacional de La Pampa (Argentina). They were ground in an Udy mill (UDY Corp. Fort Collins, CO) $1 \mathrm{~mm}$ mesh and screened by $10 \mathrm{xx}$ mesh (Universidad Nacional de La Plata, Argentina), to obtain the flour. It was defatted by extraction with hexane $\left(10 \% \mathrm{w} \mathrm{v}^{-1}\right.$ suspension) during $24 \mathrm{~h}$ at room temperature, under continuous stirring during the first $5 \mathrm{~h}$. Protein content of flour was $23.1 \pm 0.2 \%$ ( $\mathrm{w} \mathrm{w}^{-1}$ ), obtained by Kjeldahl method (AOAC, 1984) using a protein/N factor of 5.85 (Scilingo, Molina Ortiz, Martínez, \& Añón, 2002).

\subsection{Preparation of protein isolate (AI)}

The amaranth protein isolate was prepared according to Martínez and Añón (1996). The previously defatted flour was suspended in water in a relation 1:10 and the $\mathrm{pH}$ of the suspension was adjusted to 9.0 by the addition of $2 \mathrm{~mol} \mathrm{~L}^{-1} \mathrm{NaOH}$ solution. The suspension was stirred during $1 \mathrm{~h}$ and then centrifuged at $9000 \mathrm{~g}$ for $20 \mathrm{~min}$ at $10^{\circ} \mathrm{C}$. The $\mathrm{pH}$ of the supernatant was adjusted to 5.0 with $2 \mathrm{~mol} \mathrm{~L}^{-1} \mathrm{HCl}$ and centrifuged at $4{ }^{\circ} \mathrm{C}$ for $20 \mathrm{~min}$ at $9000 \mathrm{~g}$. The precipitate was suspended in water, neutralized with $0.1 \mathrm{~mol} \mathrm{~L}^{-1}$ $\mathrm{NaOH}$ and freeze-dried. The protein content of isolate was $80.6 \pm 1.0 \%$ (dry basis) as determined by Kjeldahl method.

\subsection{Protein suspension}

Suspensions of amaranth protein isolate $(\mathrm{AI})$ were prepared in buffers at pH $2.0\left(0.052 \mathrm{~mol} \mathrm{~L}^{-1} \mathrm{H}_{3} \mathrm{PO}_{4}, 0.048 \mathrm{~mol} \mathrm{~L}^{-1} \mathrm{Na}_{3} \mathrm{PO}_{4}\right.$, $0.050 \mathrm{~mol} \mathrm{~L}^{-1} \mathrm{NaCl}$, ionic strength 0.1$)$ and $\mathrm{pH} 8.0\left(0.0025 \mathrm{~mol} \mathrm{~L}^{-1}\right.$ $\mathrm{NaH}_{2} \mathrm{PO}_{4}, 0.0325 \mathrm{~m} \mathrm{~mol} \mathrm{~L}^{-1} \mathrm{Na}_{2} \mathrm{HPO}_{4}$, ionic strength 0.1 ). Reagents were from Sigma Chemicals (St. Louis, MO) with analytical grade. Buffer solutions were prepared with ultra pure water (MilliQ).

\subsection{Soluble fraction of amaranth isolate}

Amaranth isolate was suspended in the buffers at pH 2.0 and 8.0 at a protein concentration of $1 \mathrm{~g} \mathrm{~L}^{-1}$ then stirred for $1 \mathrm{~h}$ at room temperature and centrifuged at $10000 \mathrm{~g}$ for $30 \mathrm{~min}$ at $20^{\circ} \mathrm{C}$. The protein content of the supernatant was determined using the Lowry method modified by Markwell (Markwell, Haas, Bieber, \& Tolbert, 1978). The solubility is given by the ratio between the protein contents in the supernatant and the total protein content. In these conditions, the protein solubility of AI suspensions was $91.1 \pm 3.4 \%$ at $\mathrm{pH} 2.0$ and $74.9 \pm 5.6 \%$ at $\mathrm{pH}$ 8.0. The higher solubility rate in comparison to a previous publication results from the higher ionic strength used in this study (Ventureira et al., 2010).

\subsection{Differential scanning calorimetry (DSC)}

DSC measurements were performed in a TA Q100 (TA-Instruments, New Castle, DE) calorimeter calibrated at a heating rate of $10{ }^{\circ} \mathrm{C} \mathrm{min}^{-1}$ with indium, lauric acid, and stearic acid. Hermetically sealed aluminium pans were prepared to contain $10-15 \mathrm{mg}$ of isolate suspended in the buffers at $\mathrm{pH} 2.0$ and $8.0\left(10 \% \mathrm{w} \mathrm{v}^{-1}\right)$; a double empty pan was employed as reference. Capsules were heated from 20 to $140{ }^{\circ} \mathrm{C}$ at a rate of $10{ }^{\circ} \mathrm{C} \mathrm{min}{ }^{-1}$. After each run pans were punctured and their dry-matter content was determined by leaving the pans overnight in an oven at $105{ }^{\circ} \mathrm{C}$ and weighted. The denaturation temperature (Td) and enthalpy of transition $(\Delta \mathrm{H})$ were obtained by analyzing the thermograms with the Software Universal Analysis 2000 (version 4.4A.Software Plus V5.41).

\subsection{Circular dichroism (CD)}

Secondary structure differences in soluble protein solutions from $\mathrm{AI}$ at $\mathrm{pH} 2.0$ and 8.0 were determined by the absorbance of polarized light in the 190-250 far UV range. Samples were suspended $1 \mathrm{~h}$ at room temperature in a quantity to have a soluble protein concentration of $1 \mathrm{~g} \mathrm{~L}^{-1}$. They were centrifuged at $10000 \mathrm{~g}$ for $30 \mathrm{~min}$ at $20^{\circ} \mathrm{C}$ then the supernatant was poured in a quartz measure cell with a light path of $0.1 \mathrm{~mm}$ length. $C D$ measurements were carried out in a spectropolarimeter Jobin-Yvon CD6 (JobinYvon SA, Longjumeaux, France). Molar ellipticity, $\theta$ $\left(\mathrm{deg} \times \mathrm{cm}^{2} \mathrm{dmol}^{-1}\right.$ ) was calculated as Jiang, Chen, and Xiong (2009) assuming an average molecular weight of the amino acids in AI of 130. Samples were analyzed by duplicate and five spectra of each sample were used.

\subsection{Zeta-potential measurements}

The zeta-potential values of AI suspended in water at different pH values: 2.0, 4.0, 6.0 and 8.0, were measured by a laser Doppler velocimetry and phase analysis light scattering technique using a Malvern Zetasizer Nano ZS instrument (Malvern Instruments Ltd., Worcestershire, UK) at $20^{\circ} \mathrm{C}$. One $\mathrm{mL}$ of diluted sample (approximately $0.5 \mathrm{~g} \mathrm{~L}^{-1}$ ) was put in the electrophoresis cell.

\subsection{Langmuir isotherms}

The soluble fraction of AI was spread at the air-liquid interface on fully automated Wilhelmy balance Nima 601 BAM (Nima Technologies, Coventry, England) containing the buffer. The balance is equipped with a Wilhelmy plate sensor connected to a force transducer that measures continuously the surface pressure $(\pi)$. The surface pressure is defined as the difference between the surface tension of the buffer and that due to the protein film. The soluble fraction was prepared from a $2 \mathrm{~g} \mathrm{~L}^{-1}$ suspension of AI. The quantity of proteins spread at the surface was $35 \mu \mathrm{g}$ contained in $100 \mu \mathrm{L}$ of buffer. Portions of $5 \mu \mathrm{L}$ of protein solution were deposited carefully with a syringe in 20 different points distributed all along the surface at $20^{\circ} \mathrm{C}$. The protein was allowed to adsorb and stabilize at the surface for $1 \mathrm{~h}$ at $20^{\circ} \mathrm{C}$. The surface pressure-area isotherm determination was performed at $20+/-0.2{ }^{\circ} \mathrm{C}$ with a rate of $40 \mathrm{~cm}^{2} \mathrm{~min}^{-1}$.

\subsection{Interfacial tension and rheological properties of the oil-water interface}

The dynamic interfacial tension $(\gamma)$ measurements between oil and water were made using an automated drop tensiometer (Tracker IT-Concept, Longessaigne, France), described by Benjamins, Cagna, and Lucassen-Reynders (1996), with a rising drop of oil in the 
aqueous media. The apparatus analyzes the variation of the drop axial symmetric shape that was digitized and analyzed through a CCD camera coupled to a video image profile digitizer that processed the drop profiles according to the Laplace equation using Windrop software (I.T.-Concept, France).

An Exmire microsyringe (ITO Corporation, Tokyo, Japan) with an U-shaped needle containing the oil is immersed in a cuvette with the protein solution. The axysimetric drop is formed to reach a volume of $8 \mu \mathrm{L}$ that means approximately an interfacial area of $18 \mathrm{~mm}^{2}$.

The aqueous media contained the soluble fraction of $\mathrm{AI}$ in different concentrations $\left(0.05-1 \mathrm{~g} \mathrm{~L}^{-1}\right)$ in the buffers described above. The temperature was controlled by a circulated bath at $20{ }^{\circ} \mathrm{C}+/-0.1{ }^{\circ} \mathrm{C}$. The measurements were performed during 15000 s. Commercial sunflower oil from Lesieur (France) was passed by a silica column WAT051900 (Waters, Milford, MA) before use to extract polar molecules like phospholipids, free fatty acids and lipolysis or oxidation products.

The same tensiometer was used to make the measurements of the interfacial dilatational rheology. Periodical sinusoidal compressions and expansions of the drop volume were made. The surface dilatational modulus (E) was determined by the variation of the interfacial tension $(\mathrm{d} \gamma)$ resulted from a small change of the relative interfacial area $\left(\mathrm{dA} / \mathrm{A}_{0}\right)$ in the linear region of viscoelasticity. E was defined as (Gibbs, 1928): $\mathrm{E}=\mathrm{d} \gamma\left(\mathrm{dA} / \mathrm{A}_{0}\right)^{-1}$.

The frequencies of the oscillations varied from 0.005 to $0.05 \mathrm{~Hz}$ after $15000 \mathrm{~s}$ (equilibrium state) to check the response of the rheological parameters at different rates of oscillations.

Alternatively, at a concentration of $0.1 \mathrm{~g} \mathrm{~L}^{-1}$ the oscillations were made at $0.02 \mathrm{~Hz}$ in a wide range of times to observe the relationships between the interfacial tension and the dilatational modulus. The rheological parameters, elastic and viscous dilatational modulus, were taken from the variation and time of response of the interfacial tension with the oscillations. The area variations of the droplet surface were $+\mid-5 \%$ of the initial interfacial value, which has been determined to enter in the linear region of viscoelasticity.

\subsection{Preparation of oil-water emulsions}

Emulsions were prepared with either the total protein or the soluble fraction of AI. In both cases, the concentration of the protein sample was $5 \mathrm{~g} \mathrm{~L}^{-1}$ in the aqueous phase. Emulsions were prepared homogenizing $550 \mu \mathrm{L}$ of sunflower oil (Lesieur, France) and $5 \mathrm{~mL}$ of the protein sample with an ultra sound homogenizer Sonics Vibracell 500W (Sonic \& Materials INC., Newtown, CT) at a power level of 3.5 , in pulsation mode (50\%) during $5 \mathrm{~min}$, using the tapered tip immersed $15 \mathrm{~mm}$ in the liquid of the mixture contained in a plastic tube. The tube was placed into an ice bath to reduce heating during homogenization.

\subsection{Droplet size distribution}

The particle size distribution of the emulsions was determined using a Saturn Digisizer 5200 (Micromeritics Instrument Corporation, Norcross, GA) laser light scattering instrument immediately after emulsion preparation. In order to measure the individual droplet size, $125 \mu \mathrm{L}$ of the emulsions were poured in a tube containing $2875 \mu \mathrm{L}$ of $1 \%$ SDS solution to avoid flocculation. The measurement consists in recirculating diluted emulsions until an obscuration level of $8-13 \%$ is measured. Volume (\%) diameter distributions were obtained. Mean Sauter diameters, $d_{3,2}$, were calculated as: $\mathrm{d}_{3,2}=\sum_{i=1}^{N}\left(\mathrm{n}_{\mathrm{i}} \times \mathrm{d}_{\mathrm{i}}^{3}\right) / \sum_{i=1}^{N}\left(\mathrm{n}_{\mathrm{i}} \times \mathrm{d}_{i}^{2}\right)$.

The variation in values of $d_{3,2}$ at different times, in the presence or absence of SDS, was used to calculate a flocculation index $(F)$ and a coalescence index $(C)$ :

$$
\begin{aligned}
& \mathrm{F}=\left(\mathrm{d}_{3,2 \mathrm{t}}-\mathrm{d}_{3,2} \mathrm{t}+\mathrm{SDS}\right) / \mathrm{d}_{3,2} \mathrm{t}+\mathrm{SDS} \\
& \mathrm{C}=\left(\mathrm{d}_{3,2} \mathrm{t}+\mathrm{SDS}-\mathrm{d}_{3,2} \text { in }+\mathrm{SDS}\right) / \mathrm{d}_{3,2} \text { in }+\mathrm{SDS}
\end{aligned}
$$

where $d_{3,2} t$ is the value of $d_{3,2}$ at any time, $d_{3,2} t+$ sDS is $d_{3,2} t$ measured in the presence of SDS and $d_{3,2}$ in + SDS is the initial value of $d_{3,2}$ measured in the presence of SDS. The measurements were made 1 day or 7 days after emulsion preparation (storage at room temperature).

\subsection{Statistical analysis}

Data were averaged from at least two independent assays. Results are reported as mean $+/$ - standard deviation. Statistical analysis was carried out by the OriginPro 8 software (OriginLab Co., Northampton, MA). Analyses of variance were conducted. Differences between the sample means were analyzed by Fisher-LSD test using $\alpha=0.05$.

\section{Results}

\subsection{Differences of structure of AI proteins at $\mathrm{pH} 2.0$ and 8.0}

The suspensions of $\mathrm{AI}$ at $\mathrm{pH} 2.0$ and $\mathrm{pH} 8.0$ were analyzed by DSC (Fig. 1). At pH 2.0 no significant endothermic peak was observed while two endothermic peaks with denaturation temperatures $\left(\mathrm{T}_{\mathrm{d} 1}\right.$ and $\left.\mathrm{T}_{\mathrm{d} 2}\right)$ of $70.2{ }^{\circ} \mathrm{C}$ and $98.8{ }^{\circ} \mathrm{C}$ and enthalpy values of 2.2 and $8.3 \mathrm{~J} \mathrm{~g}^{-1}$ were detected at $\mathrm{pH}$ 8.0. The $\mathrm{T}_{\mathrm{d}}$ values are similar to those previously obtained by Martínez and Añón (1996) and Avanza and Añón (2007).

The disappearance of the denaturation peaks at $\mathrm{pH} 2.0$ suggests that the acidic $\mathrm{pH}$ induces an extensive unfolding of amaranth proteins and that practically no native structure persists in the proteins. On the contrary, the proteins keep their compact ordered globular conformation at pH 8.0. Similarly, different authors have reported a dissociation and unfolding of the tertiary and quaternary structures of the oligomers of soybean glycinin at acidic $\mathrm{pH}$ (Puppo \& Añón, 1999).

The far UV CD spectra of the soluble fractions of AI at pH 2.0 and pH 8.0 are shown in Fig. 2. At pH 8.0, a maximum in molar ellipticity is observed at $193 \mathrm{~nm}$. This peak was attributed to the presence of

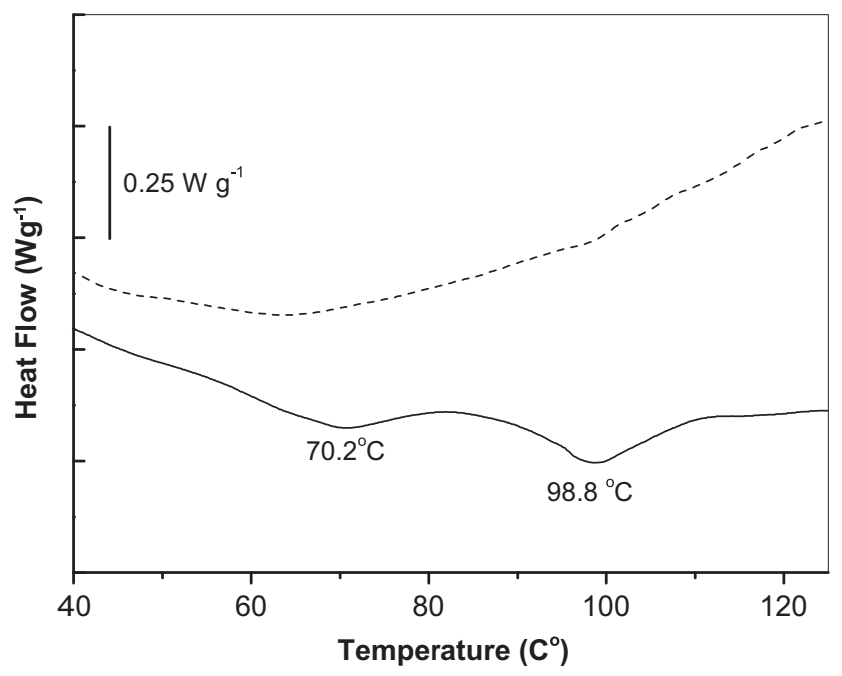

Fig. 1. DSC thermograms of AI suspensions $\left(10 \% \mathrm{w} \mathrm{v}^{-1}\right)$ at $\mathrm{pH} 2.0(--)$ and $8.0(--)$. The temperatures of thermal denaturation are indicated below the peaks. The rate of run was $10{ }^{\circ} \mathrm{C} \mathrm{min}^{-1}$. 


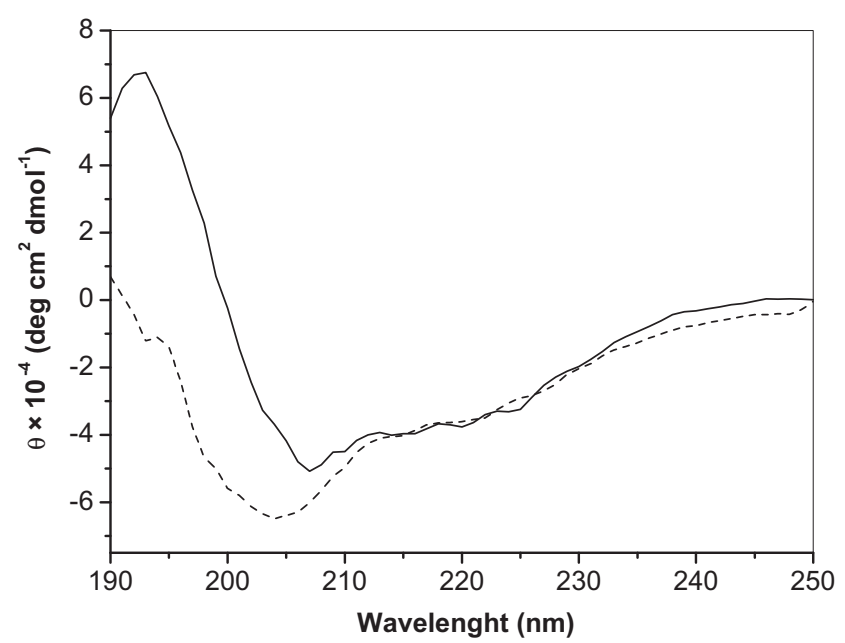

Fig. 2. Far-UV circular dichroism spectra for $\mathrm{AI}$ proteins $\left(1 \mathrm{~g} \mathrm{~L}^{-1}\right)$ at $\mathrm{pH} 2.0(--)$ and 8.0 $(-)$ in the 190-250 UV range. Samples were analyzed in duplicate.

secondary structures such as $\alpha$-helix or $\beta$-sheet (Chen, Yang, \& Chau, 1974). At pH 2.0, this maximum could not be distinguished, suggesting that these structures are more abundant at $\mathrm{pH} 8.0$ than at $\mathrm{pH}$ 2.0. At $\mathrm{pH} 8.0$, the minimum was observed at $207 \mathrm{~nm}$ while it was shifted to lower wavelengths $(204 \mathrm{~nm})$ at $\mathrm{pH} 2.0$. As the random coil arrangement shows minimum values around $195 \mathrm{~nm}$ (Chen et al., 1974), the shift detected from 207 to $204 \mathrm{~nm}$ suggests a higher quantity of random coil at $\mathrm{pH}$ 2.0. $\beta$-turns present a maximum at $207 \mathrm{~nm}$ (Greenfield, 1996) while the $\alpha$-helix structure shows minimum values at 207 and $222 \mathrm{~nm}$. The smaller ellipticity values observed at $207 \mathrm{~nm}$ at $\mathrm{pH} 2.0$ than at $\mathrm{pH} 8.0$ as well as the same ellipticity values over $212 \mathrm{~nm}$ indicate a smaller quantity of $\beta$-turns in the global conformation at $\mathrm{pH} 2.0$. Consequently, the far UV CD spectra suggest that the soluble protein fraction of AI contains less structured domains at $\mathrm{pH} 2.0$ than at pH 8.0.

Zeta potential values of AI suspensions at different pHs showed that the average electric charge of the mixture of proteins was positive at $\mathrm{pH} 2.0(25 \mathrm{mV})$ and negative at $8.0(-30 \mathrm{mV})$. These results are in agreement with the mean isoelectric point reported between 4.5 and 6.5 for different amaranth protein fractions by Konishi, Horikawa, Oku, Azumaya, and Nakatani (1991).

\subsection{Interfacial behavior}

\subsubsection{Air-water interfaces}

Comparing the behaviors at $\mathrm{pH} 2.0$ and $\mathrm{pH} 8.0$, it can be observed that the highest values of surface pressure $(\pi)$ were reached by proteins at $\mathrm{pH} 2.0$ all along the curve (Fig. $3 \mathrm{a}$ ). For the same area/protein ratio $\pi$ was more elevated at $\mathrm{pH} 2.0$ than at $\mathrm{pH}$ 8.0. This suggests that proteins are more easily spread at the interface at $\mathrm{pH} 2.0$ than $\mathrm{pH}$ 8. The curves of the first derivate from the Langmuir isotherms (Fig. $3 \mathrm{~b}$ ) show clearly two inflexion points at $\mathrm{pH} 8$ at values of 0.18 and $0.33 \mathrm{~m}^{2} \mathrm{mg}^{-1}$. These inflexion points reflect the change in organization of the biopolymers at the air-water interface versus pressure. The lack of inflexion points at $\mathrm{pH} 2.0$ indicates that in this condition proteins are in a more advanced denaturation state inducing a reduced subsequent reorganization inside the interfacial film.

\subsubsection{Oil-water interfaces}

The kinetics of adsorption at the oil-water interface at both $\mathrm{pH}$ and several concentrations of the soluble protein fraction are
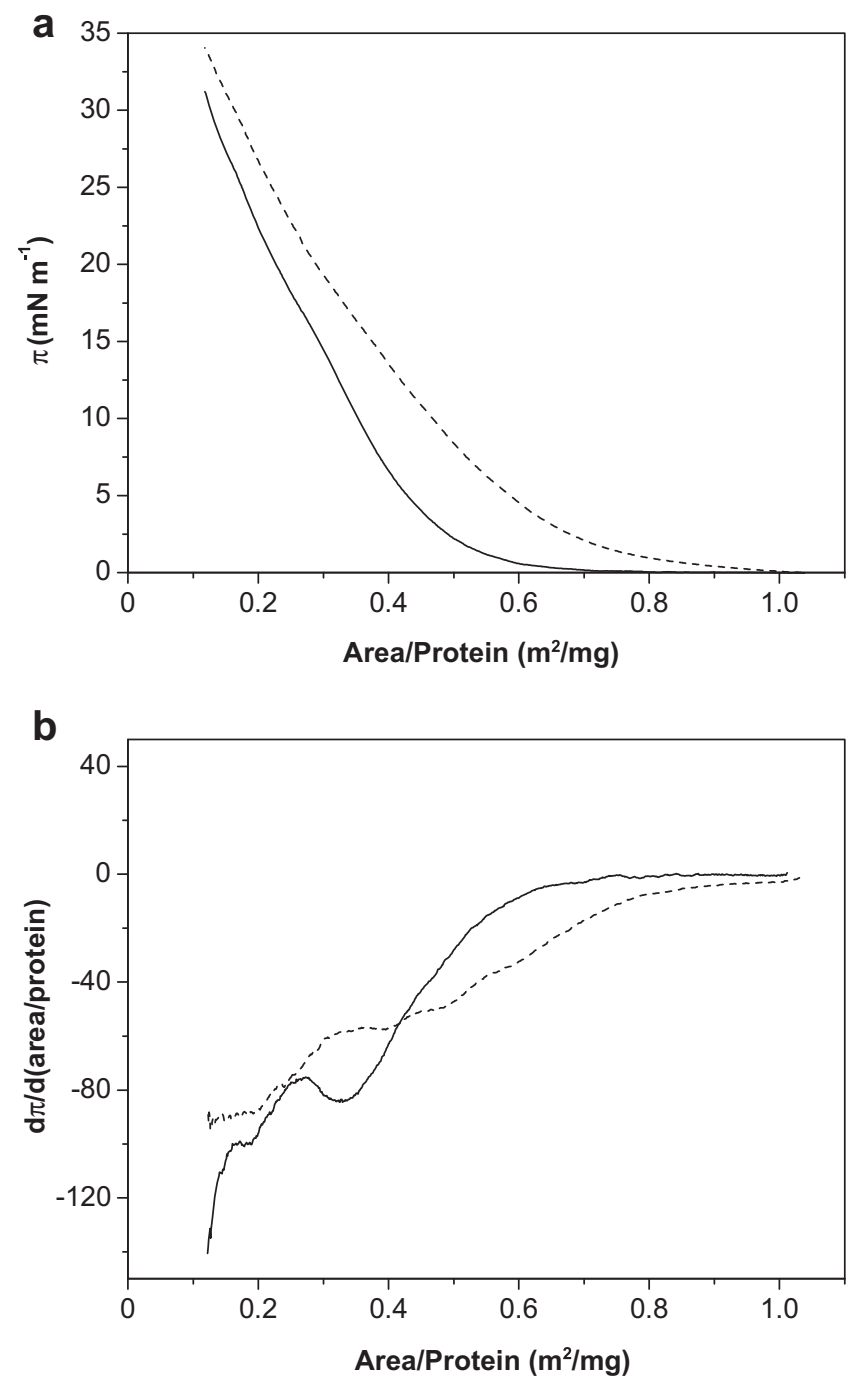

Fig. 3. (a) Surface pressure isotherms of AI proteins ( $35 \mu \mathrm{g}$ in $100 \mu \mathrm{L}$ buffer) at $\mathrm{pH} 2.0$ $(--)$ and $8.0(-)$. (b) First derivate from the surface pressure isotherms at $\mathrm{pH} 2.0(--)$ and $8.0(-)$.

shown in Fig. 4 a and b. At any concentration, the interfacial tension $(\gamma)$ at a fixed time is smaller at $\mathrm{pH} 2.0$ than at $\mathrm{pH}$ 8.0. After $15000 \mathrm{~s}$ in a $1 \mathrm{mg} \mathrm{mL}^{-1}$ concentrated solution, $\gamma$ reached a final value of around $8 \mathrm{mN}$ at $\mathrm{pH} 2.0 \mathrm{~m}^{-1}$ while $\gamma$ decreased down to $11 \mathrm{mN} \mathrm{m}^{-1}$ at $\mathrm{pH}$ 8.0. This indicates a slightly better capability to adsorb at the interface and undergo rearrangements of proteins at $\mathrm{pH} 2.0$ than at pH 8.0.

Fig. 5 a shows the rise of the complex dilatational modulus versus the time of adsorption. Whatever the $\mathrm{pH}$, this modulus is clearly supported by its elastic component $\left(E^{\prime}\right)$ whereas the viscous one $\left(E^{\prime \prime}\right)$ did not influence it strongly (results not shown). For this reason, we have expressed only the complex dilatational modulus.

These results highlight the higher values of the modulus obtained at $\mathrm{pH} 2.0$ from the beginning of the experiment. At the end it was about 3 times higher at the acidic $\mathrm{pH}$ than at basic $\mathrm{pH}$. It is noteworthy that at $\mathrm{pH} 2.0$, at $0.05 \mathrm{~h}$ of adsorption (first point) the value of dilatational modulus was similar to those reached by the proteins at $\mathrm{pH} 8.0$ at the end of the experience. Fig. $5 \mathrm{~b}$ plots the dilatational modulus versus the interfacial tension for both $\mathrm{pH}$ values. While the dilatational modulus at $\mathrm{pH} 2.0$ reached $30 \mathrm{mN} \mathrm{m}^{-1}$ at a surface tension of $20 \mathrm{mN} \mathrm{m}^{-1}$, the same value was achieved at $12.5 \mathrm{mN} \mathrm{m}^{-1}$ at $\mathrm{pH} 8.0$. These results show that the 

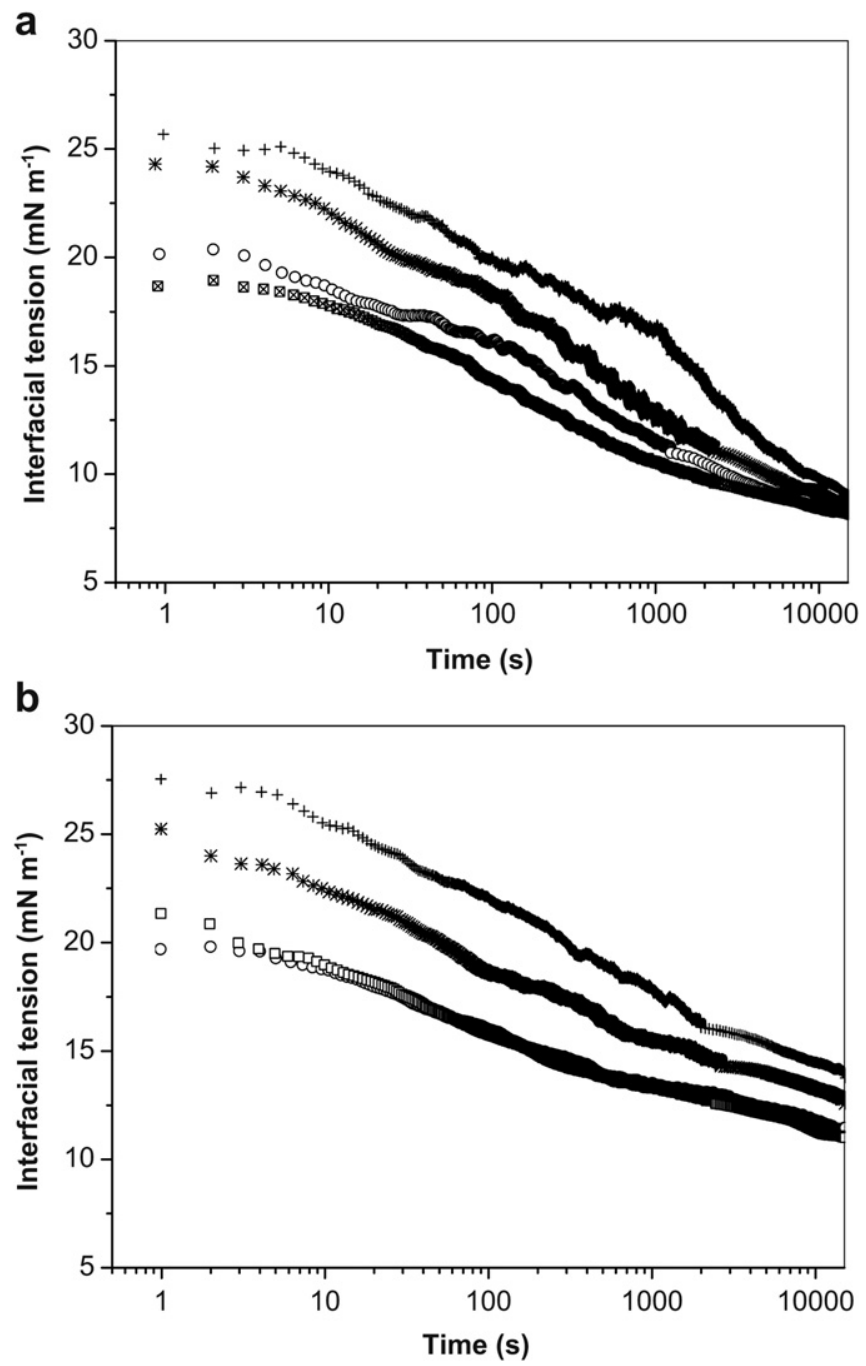

Fig. 4. Dynamic interfacial tension of AI proteins at the oil-water interface at $\mathrm{pH} 2.0$ (a), and $\mathrm{pH} 8.0$ (b) versus the concentrations in the aqueous phase: $+: 0.05 \mathrm{~g} \mathrm{~L}^{-1}$; *: $0.1 \mathrm{~g} \mathrm{~L}^{-1} ; \bigcirc 0.5 \mathrm{~g} \mathrm{~L}^{-1} ; \otimes 1 \mathrm{~g} \mathrm{~L}^{-1}$.

interface at $\mathrm{pH} 2.0$ is much more elastic and potentially less susceptible to rupture. Moreover, the slopes obtained from these plots are different between $\mathrm{pH} 2.0$ and 8.0, confirming differences in the structural characteristics of protein films.

\subsection{Emulsions}

Droplet size distribution of emulsions made with the soluble fraction or the total protein fraction of $\mathrm{AI}$ at $\mathrm{pH} 2.0$ and 8.0 are shown in Fig. 6. It can be seen that the emulsions made at pH 2.0 were very stable against coalescence with practically no appearance of droplets with higher diameters during storage, for both the soluble and the total protein fractions (Fig. $6 \mathrm{a}$ and b). At the same $\mathrm{pH}$, flocculation occurred in the emulsions, more strongly in those prepared with the total protein fraction than in those made with only the soluble protein fraction.

At pH 8.0 (Fig. 6 a), droplets exhibited a slightly weaker stability against coalescence evidenced by the increase of population of droplets with diameters of about $10 \mu \mathrm{m}$ during the storage. At $\mathrm{pH}$ 8.0, flocculation was observed with both soluble and total protein fractions, especially in the emulsions made with the total protein (Fig. $6 \mathrm{c}$ and $\mathrm{d}$ ). Table 1 lists the values of $\mathrm{d}_{3,2}$ as well as the
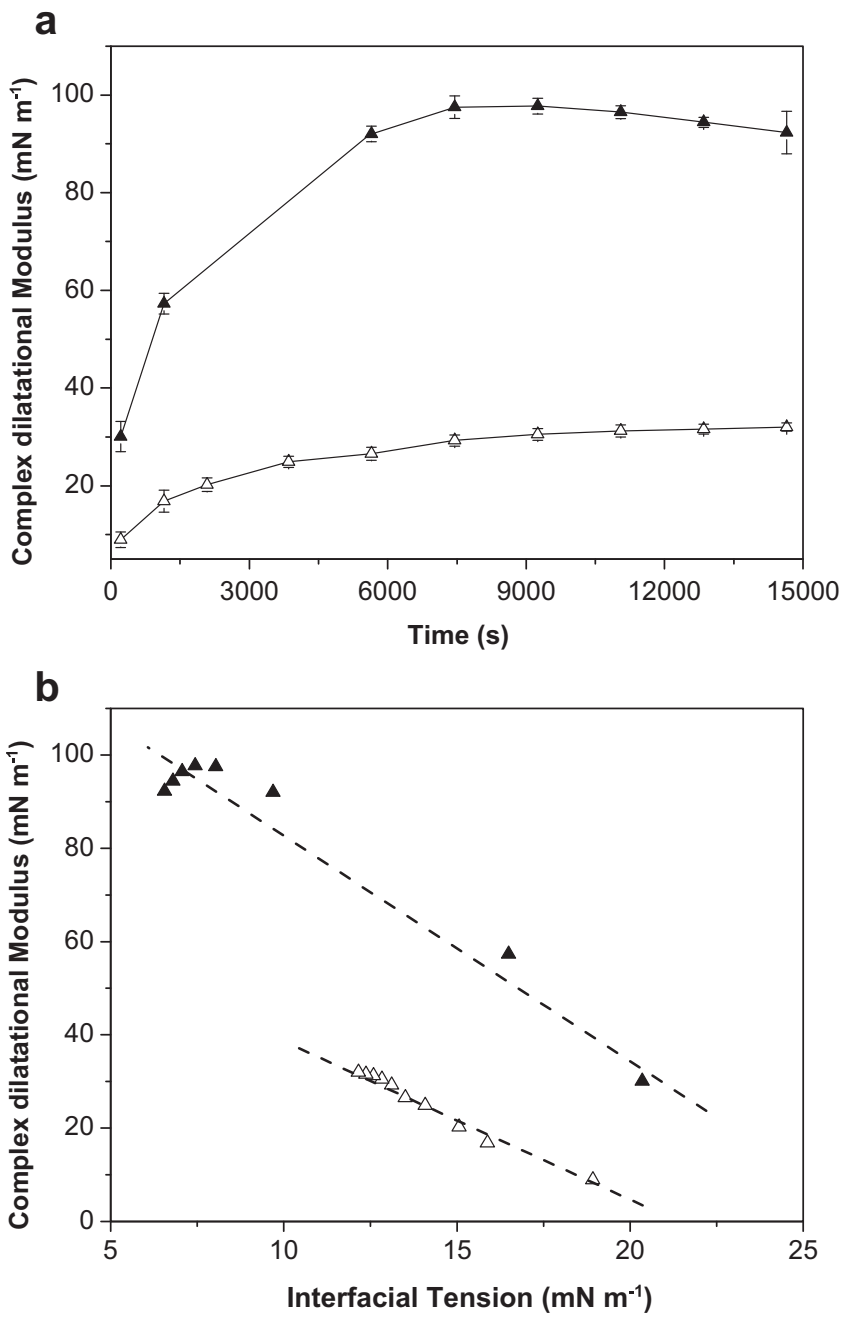

Fig. 5. (a) Variation of the complex dilatational modulus of AI protein interfaces with the time of adsorption at pH $2.0(\Delta)$ and $8.0(\Delta)$ at a concentration of $0.1 \mathrm{~g} \mathrm{~L}^{-1}$ and $0.02 \mathrm{~Hz}$. (b) Variation of the complex dilatational modulus of AI protein interfaces with the variation of the interfacial tension at $\mathrm{pH} 2.0(\boldsymbol{\Delta})$ and $8.0(\Delta)$ at a concentration of $0.1 \mathrm{~g} \mathrm{~L}^{-1}$ and $0.02 \mathrm{~Hz}$.

flocculation and coalescence indexes ( $\mathrm{F}$ and $\mathrm{C}$ respectively) for all emulsions at different storage times. It formalizes the information described from the droplet size distributions: i) the coalescence occurred only in the emulsions made at $\mathrm{pH} 8.0$, ii) the flocculation was more important in the emulsions made with the total protein fraction at both $\mathrm{pH}$ values.

\section{Discussion}

4.1. How to explain the difference of interfacial properties between the two pHs?

At pH 8.0, DSC and CD showed that the proteins contain structures such as helices and $\beta$-turns (CD) that are denaturated around $80{ }^{\circ} \mathrm{C}$ (DSC). The proteins keep most probably its globular native structure at $\mathrm{pH}$ 8.0. Usually, the compact globular structure diminishes the possibilities of the polypeptides to rearrange and to reorient at the interface. Additionally, the presence of $\beta$-turns was related with the loss of surface activity because of the decrease of molecular flexibility (Razumovsky \& Damodaran, 1999).

At $\mathrm{pH} 2.0$, the proteins present in the soluble and total protein fractions of AI were denatured (as demonstrated by DSC and CD) 

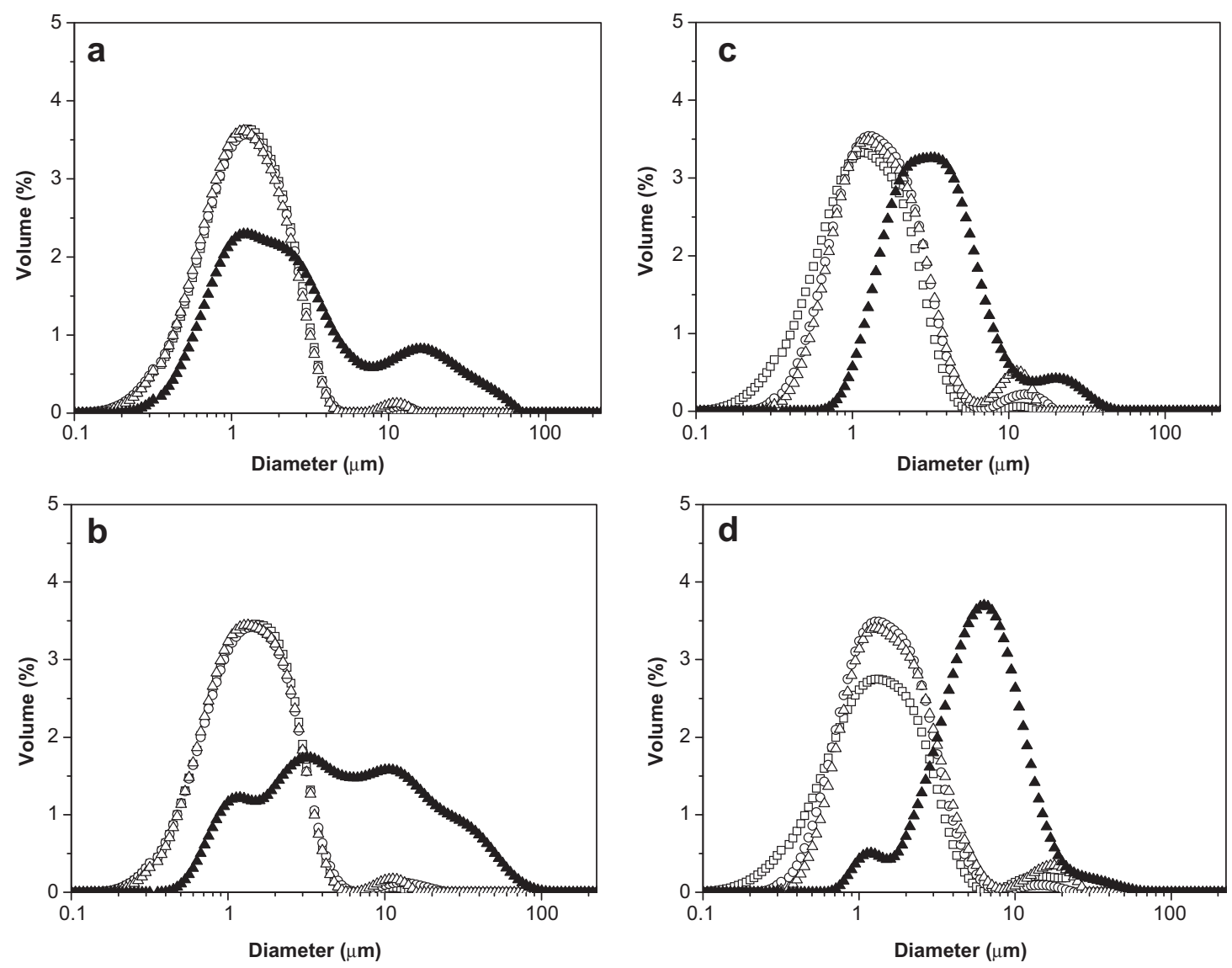

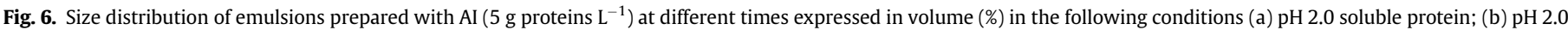

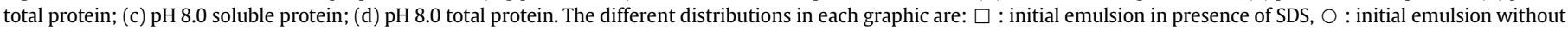
SDS, $\Delta: 7$ days stored emulsion in presence of SDS and $\boldsymbol{\Delta}: 7$ days stored emulsion without SDS.

without influence on their solubility (approx. 91\% solubility). This may explain the better efficiency of proteins to cover the interface. First, the loss in $\beta$-turns may enhance the interfacial activity (Razumovsky \& Damodaran, 1999). Second, disordered, small and flexible proteins reduce the surface tension earlier and faster than ordered, rigid and larger proteins (Beverung, Radke, \& Blanch, 1999). Unfolded proteins have more freedom to take geometrical dispositions that favor the decrease in interfacial energy and to

Table 1

Volume (\%) diameter $\left(\mathrm{d}_{3,2}\right)$, flocculation index (F) and coalescence index (C) of emulsions prepared with $\mathrm{AI}\left(5 \mathrm{~g}\right.$ proteins $\left.\mathrm{L}^{-1}\right)$ at $\mathrm{pH} 2.0$ and 8.0 with soluble and total protein, measured at different times.

\begin{tabular}{|c|c|c|c|c|}
\hline \multirow[t]{2}{*}{ Parameter } & \multicolumn{4}{|c|}{ Time of storage } \\
\hline & $\mathrm{pH} /$ Fraction & Initial & 1 day & 7 days \\
\hline \multirow[t]{4}{*}{$\mathrm{d}_{3,2 \mathrm{t}}(\mathrm{SDS})$} & $\mathrm{pH} 2.0_{\text {tot }}$ & $0.85 \pm 0.06 \mathrm{a} \mathrm{b}$ & $0.85 \pm 0.09 \mathrm{a} b$ & $0.87 \pm 0.07 \mathrm{a} \mathrm{b}$ \\
\hline & $\mathrm{pH} 2.0_{\text {sol }}$ & $0.73 \pm 0.10_{\mathrm{a}}$ & $0.74 \pm 0.11 \mathrm{a}$ & $0.75 \pm 0.09 \mathrm{a}$ \\
\hline & $\mathrm{pH} 8.0_{\text {tot }}$ & $0.71 \pm 0.04 a$ & $0.96 \pm 0.04 \mathrm{bc}$ & $1.02 \pm 0.03 \mathrm{c}$ \\
\hline & $\mathrm{pH} 8.0_{\text {sol }}$ & $0.72 \pm 0.06 \mathrm{a}$ & $0.96 \pm 0.02 \mathrm{bc}$ & $1.01 \pm 0.05_{c}$ \\
\hline \multirow[t]{4}{*}{$\mathrm{F}$} & $\mathrm{pH} 2.0_{\text {tot }}$ & $4.3 \pm 0.3 \mathrm{a} b$ & $8.4 \pm 1.3 \mathrm{c} \mathrm{d}$ & $9.7 \pm 0.8 \mathrm{c} \mathrm{d}$ \\
\hline & $\mathrm{pH} 2.0_{\text {sol }}$ & $3.5 \pm 1.7 \mathrm{a} \mathrm{b}$ & $4.0 \pm 3.3 \mathrm{a} \mathrm{b}$ & $4.7 \pm 1.9 \mathrm{abc}$ \\
\hline & $\mathrm{pH} 8.0_{\text {tot }}$ & $10.7 \pm 2.0_{\mathrm{c} \mathrm{d}}$ & $13.2 \pm 0.0_{\mathrm{d}}$ & $21.3 \pm 0.2 \mathrm{e}$ \\
\hline & $\mathrm{pH} 8.0_{\text {sol }}$ & $5.9 \pm 3.9 \mathrm{bc}$ & $3.8 \pm 4.5 \mathrm{a} \mathrm{b}$ & $3.3 \pm 4.3 \mathrm{a}$ \\
\hline \multirow[t]{4}{*}{ C } & $\mathrm{pH} 2.0_{\text {tot }}$ & - & $0.0 \pm 0.0_{a}$ & $0.3 \pm 0.1_{a}$ \\
\hline & $\mathrm{pH} 2.0_{\text {sol }}$ & - & $0.1 \pm 0.1 \mathrm{a}$ & $0.2 \pm 0.1 \mathrm{a}$ \\
\hline & $\mathrm{pH} 8.0_{\text {tot }}$ & - & $3.5 \pm 0.2 \mathrm{~b}$ & $4.3 \pm 0.5_{b}$ \\
\hline & $\mathrm{pH} 8.0_{\text {sol }}$ & - & $3.4 \pm 0.9 \mathrm{~b}$ & $4.1 \pm 0.6_{b}$ \\
\hline
\end{tabular}

Values with similar identical letters for each property indicates that the means difference is not significant at the 0.05 level (Fisher LSD 95\%). reduce the surface tension. For the same reason, the structure of the proteins at $\mathrm{pH} 2.0$ is less compact than at $\mathrm{pH} 8.0$ and a smaller amount of protein is needed to cover the same area. Consequently the thickness of the interface is expected to be thinner at $\mathrm{pH} 2.0$ than at $\mathrm{pH}$ 8.0. This assertion was verified by measuring the non adsorbed protein amount in the emulsions formulated with the proteins suspended at $\mathrm{pH} 2.0$ and at $\mathrm{pH}$ 8.0. At $\mathrm{pH} 2.0$ the quantity of non adsorbed proteins present in the aqueous phase of the emulsions was two times higher than at $\mathrm{pH}$ 8.0 (results not shown). In conclusion, the denaturation induced by $\mathrm{pH}$ leads to a better interfacial activity. It can be noticed that a similar behavior has been observed with lysozyme (Xu \& Damodaran, 1993).

\subsection{Are we able to relate interfacial characteristics and emulsifying properties?}

The rheological measurements of the interfaces showed higher values of dilatational modulus in the case of $\mathrm{pH} 2.0$ as compared to $\mathrm{pH}$ 8.0. It is known that surface elasticity is much lower for flexible proteins than for globular ones (Lucassen-Reynders, Fainerman, \& Miller, 2004). In our case we hypothesise that at pH 2.0 amaranth proteins are in a more denatured state whereas at $\mathrm{pH} 8.0$ the globular structure is more preserved. This behavior should lead to a higher surface elasticity at $\mathrm{pH} 8.0$ but we observed the opposite result. It appears then that interactions between adsorbed proteins inside the interfacial film could play a major role in the film reinforcement through hydrophobic, hydrogen or electrostatic interactions. As zeta potentials were clearly high whatever the $\mathrm{pH}$ 
(25 $\mathrm{mV}$ at $\mathrm{pH} 2.0$ and $-30 \mathrm{mV}$ at $\mathrm{pH} 8.0$ ) the track leading to hydrogen or hydrophobic interactions has to be followed to better explain these results.

Finally, the differences in elasticity at the interface can be linked to the resistance of emulsions against coalescence (Izmailova, Yampolskaya, \& Tulovskaya, 1999; Langevin, 2000). More precisely, we can consider that, as the principle of the method consists in sinusoidal deformations of the oil drop area, it can be put in relation with the phenomena occurring during storage or transport of emulsions. If we take this into account, emulsions at $\mathrm{pH} 2.0$ should be more stable against coalescence than those at $\mathrm{pH} 8.0$ and this was confirmed in our results.

Additionally, the fact that the emulsions made with total proteins showed more flocculation that those made with soluble protein originated from the nature of the sample used for the homogenization. The non soluble proteins could be adsorbed in two different interfaces at the same time and have been produced bridging flocculation. Furthermore, such aggregates may also induce depletion flocculation if they are sufficiently small. We will have to explore these hypotheses for a future study.

\section{Conclusion}

Our results clearly show that the potential use of amaranth proteins in emulsifying applications would be oriented at acidic $\mathrm{pH}$ instead of basic $\mathrm{pH}$. This conclusion is based on the better properties of $\mathrm{AI}$ at $\mathrm{pH}$ 2.0: (1) protein solubility, (2) spreading (a-w interfaces), (3) adsorption (o-w interfaces), (4) viscoelastic properties ( $0-w$ interfaces), and (5) emulsion stability.

\section{Acknowledgments}

This work was supported by the Ecos-Sud Project of France and SECyT of Argentine ( $\mathrm{N}^{\circ}$ A07B05).

\section{References}

AOAC. (1984). In Official methods of analysis (14th ed). Arlington, VA, USA: Association of Official Analytical Chemists.

Avanza, M. V., \& Añón, M. C. (2007). Effect of thermal treatment on the proteins of amaranth isolates. Journal of the Science of Food and Agriculture, 87(4), 616-623.

Barba de la Rosa, A. P., Paredes-López, O., \& Gueguen, J. (1992). Characterization of amaranth globulins by ultracentrifugation and chromatographic techniques. Journal of Agricultural and Food Chemistry, 40(6), 937-940.

Benjamins, J., Cagna, A., \& Lucassen-Reynders, E. H. (1996). Viscoelastic properties of triacylglycerol/water interfaces covered by proteins. Colloids and Surfaces A: Physicochemical and Engineering Aspects, 114, 245-254.

Beverung, C. J., Radke, C. J., \& Blanch, H. W. (1999). Protein adsorption at the oil/ water interface: characterization of adsorption kinetics by dynamic interfacial tension measurements. Biophysical Chemistry, 81(1), 59-80.

Bressani, R., \& García-Vela, L. A. (1990). Protein fractions in amaranth grain and their chemical characterization. Journal of Agricultural and Food Chemistry, 38(5) 1205-1209.

Chen, Y. H., Yang, J. T., \& Chau, K. H. (1974). Determination of the helix and $\hat{\mathrm{I}}^{2}$ form of proteins in aqueous solution by circular dichroism. Biochemistry, 13(16), 3350-3359.
Fidantsi, A., \& Doxastakis, G. (2001). Emulsifying and foaming properties of amaranth seed protein isolates. Colloids and Surfaces B: Biointerfaces, 21(1-3), 119-124.

Gibbs, J. W. (1928). Collected works. New York: Longmans.

Greenfield, N. J. (1996). Methods to estimate the conformation of proteins and polypeptides from circular dichroism data. Analytical Biochemistry, 235(1), 1-10.

Guzmán-Maldonado, S. H., \& Paredes-López, O. (1998). Production of high-protein flours as milk substitutes. In J. R. Whitaker, F. Shahidi, A. López-Munguia, R. Y. Yada, \& G. Fuller (Eds.), Functional properties of proteins and lipids, vol. 708 (pp. 66-79). Washington D. C.: American Chemical Society.

Izmailova, V. N., Yampolskaya, G. P., \& Tulovskaya, Z. D. (1999). Development of the Rehbinder's concept on structure-mechanical barrier in stability of dispersions stabilized with proteins. Colloids and Surfaces A: Physicochemical and Engineering Aspects, 160(2), 89-106.

Jiang, J., Chen, J., \& Xiong, Y. L. (2009). Structural and emulsifying properties of soy protein isolate subjected to acid and alkaline $\mathrm{pH}$-shifting processes. Journal of Agricultural and Food Chemistry, 57(16), 7576-7583.

Konishi, Y., Horikawa, K., Oku, J., Azumaya, J., \& Nakatani, N. (1991). Extraction of two albumin fractions from amaranth grains: comparison of some physicochemical properties and the putative localization in the grains. Agricultural and Biological Chemistry, 55(11), 2745-2750.

Langevin, D. (2000). Influence of interfacial rheology on foam and emulsion properties. Advances in Colloid and Interface Science, 88(1-2), 209-222.

Lucassen-Reynders, E. H., Fainerman, V. B., \& Miller, R. (2004). Surface dilatational modulus or Gibbs' elasticity of protein adsorption layers. Journal of Physical Chemistry B, 108, 9173-9176.

Markwell, M. A. K., Haas, S. M., Bieber, L. L., \& Tolbert, N. E. (1978). A modification of the Lowry procedure to simplify protein determination in membrane and lipoprotein samples. Analytical Biochemistry, 87(1), 206-210.

Martínez, E. N., \& Añón, M. C. (1996). Composition and structural characterization of Amaranth protein isolates. An electrophoretic and calorimetric study. Journal of Agricultural and Food Chemistry, 44(9), 2523-2530.

Puppo, M. C., \& Añón, M. C. (1999). Soybean protein dispersions at acid pH. Thermal and rheological properties. Journal of Food Science, 64(1), 50-56.

Razumovsky, L., \& Damodaran, S. (1999). Surface Activity-compressibility relationship of proteins at the air-water interface. Langmuir, 15(4), 1392-1399.

Rodríguez Patino, J. M., Miñones Conde, J., Linares, H. M., Pedroche Jiménez, J. J., Carrera Sánchez, C., Pizones, V., et al. (2007). Interfacial and foaming properties of enzyme-induced hydrolysis of sunflower protein isolate. Food Hydrocolloids, 21(5-6), 782-793.

Salcedo-Chávez, B., Osuna-Castro, J. A., Guevara-Lara, F., Domínguez-Domínguez, J., \& Paredes-López, O. (2002). Optimization of the isoelectric precipitation method to obtain protein isolates from amaranth (Amaranthus cruentus) seeds. Journal of Agricultural and Food Chemistry, 50(22), 6515-6520.

Scilingo, A. A., Molina Ortiz, S. E., Martínez, E. N., \& Añón, M. C. (2002). Amaranth protein isolates modified by hydrolytic and thermal treatments. Relationship between structure and solubility. Food Research International, 35(9), 855-862.

Silva-Sanchez, C., Gonzalez-Castaneda, J., de Leon-Rodriguez, A., \& Barba de la Rosa, A. P. (2004). Functional and rheological properties of amaranth albumins extracted from two Mexican varieties. Plant Foods for Human Nutrition, 59, 169-174.

Tömösközi, S., Gyenge, L., Pelcéder, A., Varga, J., Abonyi, T., \& Lásztity, R. (2008). Functional properties of protein preparations from amaranth seeds in model system. European Food Research and Technology, 226(6), 1343-1348.

Tavano, O. L., Da Silva, S. I., Jr., Demonte, A., \& Neves, V. A. (2008). Nutritional responses of rats to diets based on chickpea (Cicer arietinum L.) seed meal or its protein fractions. Journal of Agricultural and Food Chemistry, 56(22), 11006-11010.

Thanapornpoonpong, S. N., Vearasilp, S., Pawelzik, E., \& Gorinstein, S. (2008). Influence of various nitrogen applications on protein and amino acid profiles of amaranth and quinoa. Journal of Agricultural and Food Chemistry, 56(23), 11464-11470.

Ventureira, J., Martínez, E. N., \& Añón, M. C. (2010). Stability of oil: Water emulsions of amaranth proteins. Effect of hydrolysis and pH. Food Hydrocolloids, 24(6/7), 551-559.

Xu, S., \& Damodaran, S. (1993). Comparative adsorption of native and denatured egg-white, human, and T4 phage lysozymes at the air-water interface. Journal of Colloid and Interface Science, 159(1), 124-133. 